\title{
PREDICTION OF BODY FATNESS FROM BODY MEASUREMENTS IN NEW ZEALAND WHITE RABBITS
}

\author{
G.F. Gouda* and A.R. Shemeis
}

Animal Production Department, Faculty of Agriculture, Ain Shams University, Shoubra El-Kheima, 11241

Cairo Egypt

*Corresponding Email: gouda fathi@yahoo.com

\section{SUMMARY}

Possibilities of predicting body fatness from body measurements were examined using 121 New Zealand White rabbits aged 90 days. Body measurements included body weight at marketing age (FBW), heart girth $(H G)$, abdomen circumference $(A C)$ and chest width $(C W)$. The fatness indicating traits $(F I T)$ were weights of total body fat (TBFW), non-carcass fat (NCFW), subcutaneous fat (SCFW) and inter muscular fat (IMFW) and TBFW as percentage of marketing body weight (TBFP). Each of FIT was highly significantly correlated with $F B W(0.79$ to 0.91$), H G(0.76$ to 0.86$), A C(0.70$ to 0.85$)$ and $C W(0.73$ to 0.81$)$. Several prediction equations based on final body weight and linear body measurements alone (simple regression) and on final body weight and linear measurements simultaneously (stepwise regression) were developed. Prediction of FIT based on final body weight alone was more accurate $\left(R^{2}=0.62\right.$ to 0.82) than that based on individual linear body measurements with the HG being the most accurate predictor within this group. The inclusion of final body weight and linear body measurements into one equation did not increase the accuracy of prediction $(+2 \%$ to +9\%). The results further indicate that final body weight alone is a reasonably accurate predictor for body fatness expressed in gram using the equation: $T B F W=-120.39+0.102 F B W\left(R^{2}=0.82\right)$ or as percentage of final body weight using the equation: TBFP=-2.96 +0.004 FBW $\left(R^{2}=0.67\right)$ or expressed in grams of noncarcass fat: $N C F W=-63.89+0.053 F B W\left(R^{2}=0.82\right)$ or subcutaneous fat: $S C F W=-22.73+0.019 F B W\left(R^{2}=\right.$ $0.62)$ or inter muscular fat: $I M F W=-33.66+0.029 F B W\left(R^{2}=0.76\right)$.

\section{Keywords: body fatness, body measurements, prediction equations, New Zealand White rabbits}

\section{INTRODUCTION}

Over the last three decades, rabbit meat has gained wide popularity among consumers mainly for their health benefits. Compared with red meats, rabbit meat is usually considered as low fat meat (Dalle Zotte, 2002). This is due to the low conversion rate of grams of usable protein into $\mathrm{K}$ calorie in meat, which is 105 for rabbit meat, 427 for sheep meat and 442 for beef (Lebas et al., 1986). The chemical composition of lipid component in rabbit is extremely variable, ranging from $3.6 \%$ (Ouhayoun et al., 1981) to $7.1 \%$ (Pla et al., 2004). This range of variation may impact the consumer desire for rabbit meat. Moreover, the poor partition of fat component between depots is a problem for rabbit breeders and processors for waste dietary energy, management and product yield. Prediction of body fatness using correlated indicators will enable the rabbit breeder select against body fatness thereby enhancing the quality of its meat. Previous studies on rabbits showed relationships between linear body measurements and carcass attributes (Lukefahr and Ozimba, 1991; Shemeis and Abdallah, 2000; Pinna et al., 2004 and Ogah , 2012). However, there is lack of information on the relationship between body fatness and body measurements. This information gap necessitated the interest shown in the current study.

The aim of the present study was to develop simple and multiple regression equations to predict body fatness in New Zealand White rabbits using body measurements.

\section{MATERIAL AND METHODS}

\section{Source of data:}

A total of 121 New Zealand White rabbits were chosen randomly at marketing age (90 days) to be slaughtered. The rabbits were born (march- April, 1996) in private rabbit farm and slaughtered, dressed out and dissected in the Meat Laboratory of Animal Production Department, Faculty of Agriculture, Ain Shams University.

\section{Management of Animals:}

At 28 days of age, weaning age, rabbits were separated from their dams into fattening batteries. They were fed ad libitum a commercial pelleted diets providing $2800 \mathrm{~K}$. Cal. digestible energy $/ \mathrm{kg}$ diet until marketing age (90 days).

\section{Traits Measured:}

At marketing, rabbits were weighed (FBW) and transferred to the Meat Laboratory of Animal Production Department, Faculty of Agriculture, Ain Shams University. They were measured for body dimensions according to the procedures described by Blasco et al. (1992). They were then slaughtered and dressed within one hour of their arrival with the heart, mesenteric, caul and kidney knob and channel fats removed and weighed (NCFW). Carcasses were 
held at $2{ }^{\circ} \mathrm{C}$ for 24 hours before subcutaneous fat (SCFW) and intermuscular fat (IMFW) of the right side were dissected and weighed. Weights of SCFW and IMFW were multiplied by two and added to weights of the non-carcass fat (NCFW) depots to give total body fat (TBFW) according to the method described by Shemeis et al., 1994). Total body fat weight as $\%$ of body weight (TBFP) was calculated.

\section{Statistical Analyses:}

Each dependent variable (TBFW, TBFP,SCFW, IMFW and NCFW) was predicted from the body measurements using the following regression models:

Single variable model

Multiple variables

model:

$$
\begin{array}{r}
Y_{i}=\mathbf{a}+b_{x_{i}}+\mathbf{e}_{i} \\
Y_{i}=\mathbf{a}+\mathbf{b}_{1} \mathbf{X}_{1 i}+ \\
\mathbf{b}_{2} \mathbf{X}_{2 \mathrm{i}}+\ldots+\mathbf{b}_{\mathrm{p}} \mathbf{X}_{\mathrm{pi}}+\mathbf{e}_{\mathrm{i}}
\end{array}
$$

Where :

$Y_{i}=$ the dependent variable (fatness indicating traits) of the $i^{\text {th }}$ rabbit;

$\mathrm{x}_{\mathrm{i}}=$ the $\mathrm{i}^{\text {th }}$ independent variables

$\mathrm{a}=$ intercept;

$\mathrm{X}_{\mathrm{pi}}=$ the $\mathrm{p}^{\mathrm{th}}$ independent variable (linear body measurements) of the $i^{\text {th }}$ rabbit;

$b_{1}, b_{2}, \ldots, b_{P}=$ partial regression coefficients of $Y$ on X's; and

$e_{i}=$ error assumed to be $\operatorname{NID}\left(0, \sigma_{e}^{2}\right)$.

The regression analysis was performed using the REG procedure of SAS (2001)

\section{Detecting Multicollinearity:}

To indicate Multicollinearity, a high degree of correlation among the independent variables, as among the considered predictors in the present study, tolerance value and variance inflation factor value (VIF) were calculated according to Montgomery (2001).

\section{RESULTS AND DISCUSSION}

Means and coefficients of variation for body measurements and body fatness indicating traits are given in Table (1).

It appeared that the coefficients of variability for the traits describing body weight $(16.9 \%)$, heart girth (7.6\%), abdomen circumference $(7.0 \%)$ and chest width $(12.3 \%)$ were obviously lower than those for body fatness indicating traits (37.2 to $56.2 \%)$. The variability in total body fat in absolute value was lowered by $11 \%$ when expressed as percentage of final body weight (48.6 vs. 37.2\%).

\section{Correlations:}

Correlation coefficients between body FIT and body measurements are given in Table (2).

Linear body measurements showed highly significant and comparable positive correlations with total body fat weight $(0.81$ to 0.91$)$, total body fat weight expressed as a percentage of final body weight (0.77 to 0.82$)$, non-carcass fat weight (0.81 to $0.91)$, subcutaneous fat weight $(0.70$ to 0.79$)$ and intermuscular fat weight $(0.76$ to 0.87$)$. These correlations indicate that the body weight and linear body measurements could be used to predict body fatness indicating traits with reasonable accuracy.

The high positive correlation obtained in the present study between final body weight and heart girth (0.87, Table 2; 0.86, Akinsola et al., 2014; 0.84, Udeh, 2013; 0.92, Afolabi et al., 2012; 0.76, Hassan et al., 2012; 0.62, Okoro et al., 2010; 0.91, Yakubu and Ayoade, 2009), final body weight and chest width $(0.85$, Table $2 ; 0.75-0.87$, Shahin and Hassan, 2000), final body weight and abdominal circumference $(0.87$, Table $2 ; 0.67$, Hassan et al., 2012) indicated the necessity of testing these predictors for multicollinearity.

Table 1. Means $(\bar{X})$, standard errors (SE) and coefficient of variations (CV \%) of body measurements and body fatness

\begin{tabular}{lcc}
\hline Trait & $\bar{X} \pm$ SE & CV (\%) \\
\hline Body measurements : & & 16.9 \\
- Final weight (g) & $1919 \pm 29.5$ & 7.6 \\
- Heart girth (cm) & $23.4 \pm 0.2$ & 7.0 \\
- Abdomen circumference (cm) & $26.0 \pm 0.2$ & 12.3 \\
- Chest width (cm) & $5.5 \pm 0.1$ & 48.6 \\
Body Fatness : & & 37.2 \\
- Total body fat weight (gm) & $75.0 \pm 3.3$ & 49.6 \\
- Total body fat percentage * & $3.4 \pm 0.1$ & 56.2 \\
- Non-carcass fat weight (g) & $38.6 \pm 1.7$ & 49.0 \\
- Total subcutaneous fat weight (g) & $14.2 \pm 0.7$ & $22.2 \pm 1.0$ \\
$\quad$ - Total intermuscular fat weight (g) & &
\end{tabular}


Table 2. Simple correlation coefficients* between body measurements and body fatness indicating traits and between them

\begin{tabular}{|c|c|c|c|c|c|c|c|c|c|}
\hline \multirow{2}{*}{ Trait } & \multicolumn{4}{|c|}{ Body measurements } & \multicolumn{5}{|c|}{ Body Fatness } \\
\hline & FBW & HG & $\mathrm{AC}$ & CW & TBFW & TBFP & NCFW & SCFW & IMFW \\
\hline \multicolumn{10}{|l|}{ Body measurements } \\
\hline $\begin{array}{l}\text { Final weight } \\
\text { (FBW) }\end{array}$ & - & 0.87 & 0.87 & 0.85 & 0.91 & 0.82 & 0.91 & 0.79 & 0.87 \\
\hline $\begin{array}{l}\text { Heart girth } \\
(\mathrm{HG})\end{array}$ & & - & 0.80 & 0.83 & 0.86 & 0.82 & 0.85 & 0.76 & 0.84 \\
\hline $\begin{array}{l}\text { Abdomen circumference } \\
\text { (AC) }\end{array}$ & & & - & 0.75 & 0.84 & 0.79 & 0.85 & 0.70 & 0.82 \\
\hline $\begin{array}{l}\text { Chest width } \\
(\mathrm{CW})\end{array}$ & & & & - & 0.81 & 0.77 & 0.81 & 0.73 & 0.76 \\
\hline \multicolumn{10}{|l|}{ Body Fatness } \\
\hline $\begin{array}{l}\text { Total body fat weight } \\
\text { (TBFW) }\end{array}$ & & & & & - & 0.98 & 0.98 & 0.90 & 0.97 \\
\hline $\begin{array}{l}\text { Total body fat percentage } \\
\text { (TBFP) }\end{array}$ & & & & & & - & 0.95 & 0.89 & 0.95 \\
\hline $\begin{array}{l}\text { Non-carcass fat weight } \\
\text { (NCFW) }\end{array}$ & & & & & & & - & 0.82 & 0.92 \\
\hline $\begin{array}{l}\text { Total subcutaneous fat } \\
\text { weight (SCFW) }\end{array}$ & & & & & & & & - & 0.84 \\
\hline $\begin{array}{l}\text { Total intermuscular fat } \\
\text { weight (IMFW) }\end{array}$ & & & & & & & & & - \\
\hline
\end{tabular}

Table 3. Diagnoses of multicollinearity among the predictors

\begin{tabular}{lcc}
\hline Predictor & Tolerance value $^{\mathbf{a}}$ & Variance inflation value $^{\mathbf{b}}$ \\
\hline Final body weight & 0.14 & 7.38 \\
Heart girth & 0.20 & 5.10 \\
Abdominal circumference & 0.24 & 4.18 \\
Chest width & 0.24 & 4.25 \\
\hline
\end{tabular}

a: Tolerance value less than 0.10 indicates collinearity,

b: VIF value greater than 10 indicates collinearity.

\section{Multicolinearity:}

Values of tolerance and variance inflation factor of the predictors are given in Table (3). Tolerance value represents the amount of variability in independent variable that is not explained by other independent variables. The tolerance values indicated that $14 \%$ of the variability in final body weight is not explained by linear body measurements. The corresponding figures were $20 \%$ for heart girth and $24 \%$ for each of abdominal circumference and chest width. The values of VIF illustrated that $92.62 \%$ of the variance in final body weight could be explained by linear body measurements. The corresponding figures were $94.90 \%$ for heart girth, $95.82 \%$ for abdominal circumference and $95.75 \%$ for chest width. These results indicate that the degree of multicollinearity among the four predictors could be negligible. So, these findings can be trusted and applied to other samples.

\section{Prediction Equations:}

The regression equations for predicting body fatness from final body weight, heart girth, abdominal circumference and chest width with their accuracy of prediction $\left(\mathrm{R}^{2}\right)$ values are given in Table (4).

Prediction of total body fat weight from final body weight alone $\left(\mathrm{E}_{1}\right)$ was more accurate $\left(\mathrm{R}^{2}=\right.$ $0.82)$ than that based on heart girth alone $\left(R^{2}=0.75\right)$, abdomen circumference alone $\left(\mathrm{R}^{2}=0.71\right)$ and chest width alone $\left(\mathrm{R}^{2}=0.66\right)$. Adding linear body measurements to final body weight (the best single predictor) to formulate $\mathrm{E}_{5}$ didn't increase accuracy of prediction drastically $\left(\mathrm{R}^{2}=0.85, \mathrm{E}_{5}\right.$ vs $\left.0.82, \mathrm{E}_{1}\right)$. This is due to the strong correlation among the predictors $(\mathrm{r}=0.75$ to 0.87$)$.

Expressing total body fat weight as percentage of marketing body weight was associated with higher reduction in prediction accuracy using final body weight alone $\left(\mathrm{R}^{2}=0.67\right.$ vs 0.82$)$, heart girth alone $\left(\mathrm{R}^{2}=0.67\right.$ vs 0.75$)$, abdominal circumference alone $\left(\mathrm{R}^{2}=0.62\right.$ vs 0.71$)$ and chest width alone $\left(\mathrm{R}^{2}=0.59\right.$ vs 0.66$)$. Prediction accuracy was decreased by $12 \%$ unit with the four traits as predictors $\left(\mathrm{E}_{10} v s \mathrm{E}_{5}\right)$.

Accuracy of predictions of total non-carcass fat weight was similar to those obtained for total body fat weight. This similarity was found using either 
single variable models $\left(\mathrm{R}^{2}=0.66\right.$ to 0.82 for each of $E_{1}$ to $E_{4}$ and $E_{11}$ to $E_{14}$ ) or multiple variables model $\left(\mathrm{R}^{2}=0.85\right.$ for $\mathrm{E}_{5}$ vs 0.84 for $\left.\mathrm{E}_{15}\right)$.

Prediction of subcutaneous fat weight from final body weight alone $\left(\mathrm{E}_{16}\right)$ was more accurate than that based on heart girth alone $\left(\mathrm{E}_{17}\right)$ by $4 \%$, abdomen circumference alone $\left(\mathrm{E}_{18}\right)$ by $12 \%$ and chest width alone $\left(\mathrm{E}_{19}\right)$ by $9 \%$. As compared with prediction based on final body weight alone $\left(R^{2}=0.62, E_{16}\right)$, adding heart girth, abdominal circumference and chest width to formulate $\mathrm{E}_{20}$ was not useful in increasing accuracy of prediction $\left(\mathrm{R}^{2}=0.64\right)$.

Prediction of intermuscular fat using the same predictors appears that the four predictors were more accurate in predicting the weight of intermuscular fat $\left(\mathrm{R}^{2}=0.58\right.$ to 0.76 for single trait model and 0.80 for the multiple trait model) than that of subcutaneous fat $\left(\mathrm{R}^{2}=0.50\right.$ to 0.62 for the single trait model and 0.64 for the multiple trait model).

\section{CONCLUSION}

The results obtained in the present study permit to use the final body weight (FBW) alone as a reasonably accurate predictor for body fatness

Table 4. Prediction equations for body fatness indicating traits from live performance traits one decimal

\begin{tabular}{|c|c|c|c|c|c|c|c|c|c|}
\hline \multirow{2}{*}{$\begin{array}{l}\text { Dependent } \\
\text { trait }\end{array}$} & \multirow[b]{2}{*}{$\begin{array}{l}\text { Model } \\
\text { type }^{\mathrm{T}}\end{array}$} & \multirow{2}{*}{$\begin{array}{c}\text { Equation } \\
\text { No. } \\
\text { (E) }\end{array}$} & \multirow[b]{2}{*}{ Intercept } & \multicolumn{4}{|c|}{ b-Values ${ }^{\text {a }}$} & \multirow[b]{2}{*}{$\mathbf{R}^{2}$} & \multirow{2}{*}{$\begin{array}{l}\text { R.E } \\
(\%)^{b}\end{array}$} \\
\hline & & & & FW & HG & AC & $\mathbf{C W}$ & & \\
\hline \multirow{5}{*}{$\begin{array}{l}\text { Total } \\
\text { Body } \\
\text { fat weight } \\
(\text { gm) } \\
\end{array}$} & \multirow{4}{*}{ SVM } & 1 & -120.39 & 0.102 & - & - & - & 0.82 & 100.00 \\
\hline & & 2 & -336.44 & - & 17.59 & - & - & 0.75 & 91.46 \\
\hline & & 3 & -361.468 & - & - & 16.79 & - & 0.71 & 86.59 \\
\hline & & 4 & -164.828 & - & - & - & 43.46 & 0.66 & 80.49 \\
\hline & MVM & 5 & -254.701 & 0.059 & 5.45 & 3.43 & - & 0.85 & 103.66 \\
\hline \multirow{5}{*}{$\begin{array}{l}\text { Total } \\
\text { body fat as } \\
\text { percentage of } \\
\text { final body } \\
\text { weight }\end{array}$} & \multirow{4}{*}{ SVM } & 6 & -2.96 & 0.004 & - & - & - & 0.67 & 100.00 \\
\hline & & 7 & -11.08 & - & 0.633 & - & - & 0.67 & 100.00 \\
\hline & & 8 & -11.759 & - & - & 0.595 & - & 0.62 & 92.54 \\
\hline & & 9 & -4.884 & - & - & - & 1.56 & 0.59 & 88.06 \\
\hline & MVM & 10 & -10.384 & 0.001 & 0.306 & 0.185 & - & 0.73 & 108.96 \\
\hline \multirow{5}{*}{$\begin{array}{l}\text { Total } \\
\text { Non-carcass } \\
\text { fat weight } \\
\text { (gm) }\end{array}$} & \multirow{4}{*}{ SVM } & 11 & -63.89 & 0.053 & - & - & - & 0.82 & 100.00 \\
\hline & & 12 & -173.867 & - & 9.085 & - & - & 0.72 & 87.81 \\
\hline & & 13 & -191.688 & - & - & 8.857 & - & 0.71 & 86.59 \\
\hline & & 14 & -87.328 & - & - & - & 22.83 & 0.66 & 80.49 \\
\hline & MVM & 15 & -130.130 & 0.033 & 2.196 & 2.113 & - & 0.84 & 102.44 \\
\hline \multirow{5}{*}{$\begin{array}{l}\text { Total } \\
\text { Subcutaneous } \\
\text { fat weight } \\
\text { (gm) }\end{array}$} & \multirow{4}{*}{ SVM } & 16 & -22.73 & 0.019 & - & - & - & 0.62 & 100.00 \\
\hline & & 17 & -65.06 & - & 3.387 & - & - & 0.58 & 93.55 \\
\hline & & 18 & -65.467 & - & - & 3.063 & - & 0.50 & 80.65 \\
\hline & & 19 & -32.755 & - & - & - & 8.50 & 0.53 & 85.48 \\
\hline & MVM & 20 & -42.784 & 0.012 & 1.416 & - & - & 0.64 & 103.23 \\
\hline \multirow{5}{*}{$\begin{array}{l}\text { Total } \\
\text { intermuscular } \\
\text { fat weight } \\
(\mathrm{gm})\end{array}$} & \multirow{4}{*}{ SVM } & 21 & -33.66 & 0.029 & - & - & - & 0.76 & 100.00 \\
\hline & & 22 & -97.52 & - & 5.118 & - & - & 0.71 & 93.42 \\
\hline & & 23 & -104.313 & - & - & 4.865 & - & 0.67 & 88.16 \\
\hline & & 24 & -44.745 & - & - & - & 12.13 & 0.58 & 76.32 \\
\hline & MVM & 28 & -79.593 & 0.015 & 1.864 & 1.167 & - & 0.80 & 105.26 \\
\hline
\end{tabular}

T:SVM= single variable model; MVM= Multiple variables model;

a: FW : final weight; $\mathrm{CC}$ : chest circumference ; $\mathrm{AC}$ : abdomen circumference; $\mathrm{CW}$ : chest width;

b: calculated relative to final weight accuracy 


\section{REFERENCES}

Afolabi K. D., P. O. Orimoloye, A. A. Awah, B. C. Lalabe and F. O. Odekina, 2012. Estimation of inter-relationship between body weight and morphometric structural measurements of domestic rabbits reared under matured rubber plantation. World Journal of Young Researchers, 2 (5): 83-87.

Akinsola O.M., B.I. Nwagub, M. Orunmuyia, G.T. Iyeghe-Erakpotoborb, E.D Ezec, A.J. Shoyomboa, E.U. Okudaa and U. Louisd, 2014. Prediction of bodyweight from body measurements in rabbits using principal component analysis. Scientific Journal of Animal Science, 3 (1) 15-21.

Blasco A., J. Ouhayoun, and G. Masoero, 1992. Study of rabbit meat and carcass criteria and terminology. Journal of Applied Rabbit Research, 15: 775-786.

Dalle Zotte, 2002. Perception of rabbit meat quality and major factors influencing the rabbit carcass and meat quality. Livestock Production Science, 75: $11-32$

Hassan H. E., K. M. Elamin, I. A. Yousif, A. M. Musa and M. A. Elkhairey, 2012. Evaluation of Body Weight and some Morphometric Traits at Various Ages in Local Rabbits of Sudan. Journal of Animal Science Advances, 2 (4): 407-415.

Lebas F., P. Coudert, R. Rouvier, and H. de Rochambeau, 1986. The rabbit: husbandry, health and production. Food and Agriculture Organization of the United Nation. Animal Production and Health Series, No. 21. FAO, Rome.

Lukefahr S. D. and C. E. Ozimba, 1991. Prediction of carcass merit from live body measurements in rabbit of four breed - types. Livestock Production Science, 29: 323-334.

Montgomery D., 2001. Design and Analysis of Experiments (fifth edition), John Wiley and Sons, 684 page.

Ogah D.M., 2012. Canonical correlation analysis of body measurements and carcass traits of cross bred rabbit population. Biotechnology in Animal Husbandry, 28: p 855-861.
Okoro V. M. O., C.T. Ezeokeke, U. E. Ogundu and C. Chukwudum,, 2010. Phenotypic correlation of bodyweight and linear body measurement in Chinchilla rabbits (Orycotolagus cuniculus). Journal of Agricultural Biotechnology and Sustainable Development, 2 (2): 027-029.

Ouhayoun J., Y. Demarne and F. Lebas, 1981. Utilisation de pellicules de colza dans l'alimentation du lapin en croissance. Effet sur la qualité des carcasses. Annales de Zootechnie, 30 (3): 325-333.

Pinna W., M. L. Marongiu, P. Sedda, G. Moniello, A. Nizza, and G. Piccolo, 2004. Linear measurements of carcass as a tool to improve the evaluation of the rabbit meat production.in proc. 8th world rabbit congress, September 7-10, Puebla, Mexico :1447-1451.

Pla M., M. Pascual and B. Ariño, 2004. Protein, fat and moisture content of retail cuts of rabbit meat evaluated with the NIRS methodology. World Rabbit Science, 12 (3): 149 - 158.

SAS Institute, 2001. SAS/STAT User's Guide: Statistics. SAS Institute Inc., Cary, NC.

Shahin K. A. and N.S. Hassan, 2000. Sources of shared variability among body shape characters at marketing age in New Zealand White and Egyptian rabbit breeds. Annales de Zootechnie, 49: 435-445.

Shemeis A.R. and O.Y. Abdallah, 2000. Possibilities of developing Favourable body fat partition via selection indexes - Application on rabbits. Archiv Tierzucht Dummerstorf, 43 (2): 193-201.

Shemeis A.R., T. Liboriussen, B. Bech Andersen, O.Y. Abdallah, 1994. Offal components, body fat partition, carcass composition and carcass tissues distribution in Danish Friesian cull cows of different age and body condition. Livestock Production Science, 40 (2): 165-170.

Udeh I., 2013. Prediction of body weight in rabbits using principal component factor scores in multiple linear regression model. Rabbit Genetics, 3 (1): 1-6.

Yakubu A. and J. A. Ayoade, 2009. Application of principal component factor analysis in quantifying size and morphological indices of domestic rabbits. International Journal of Morphology, 27(4):1013-1017. 


\section{التتبؤ بتدهن الجسم اعتماداً على مقاييس الجسم فى أرانب النيوزيلندى الابيض جودة فتحى جودة، احمد راغب شميس قسم الانتاج الحيوانى، كلية الزراعة ، جامعة عين شمس ، شبرا الخيمة ، أ أ 1 ألقاهرة، مصر}

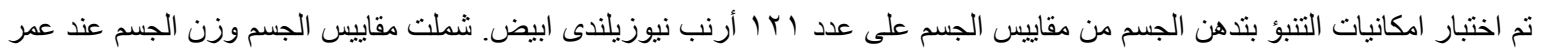

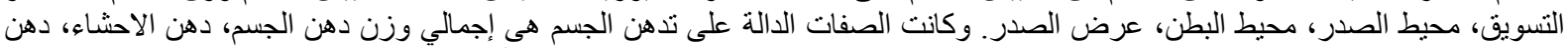

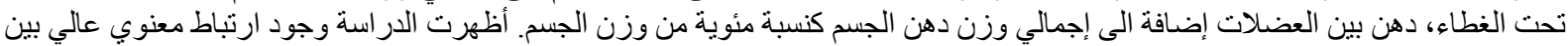

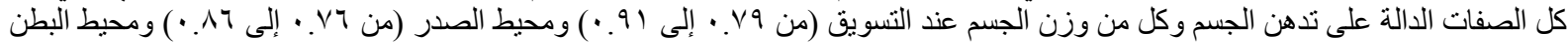

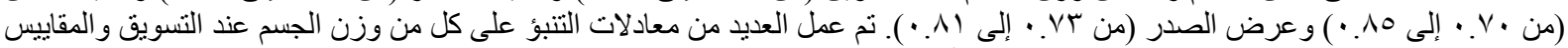

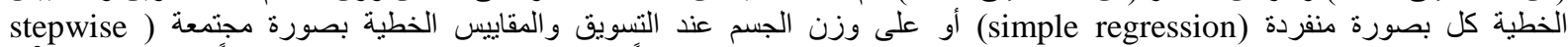
R = regression

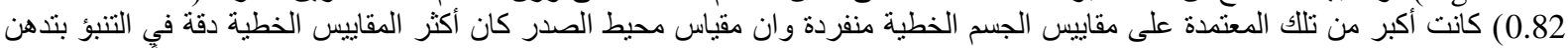

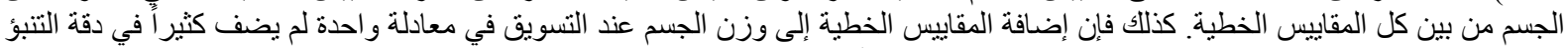

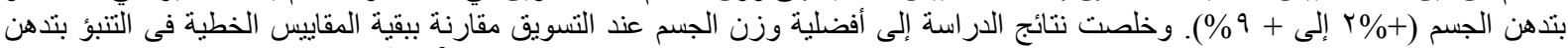

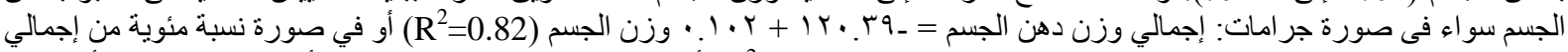

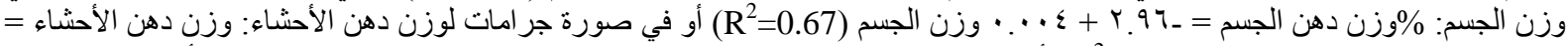

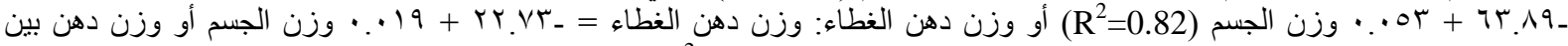

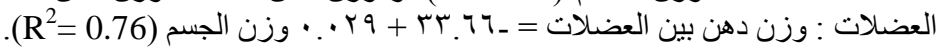

